\title{
VOLCANIC ACTIVITY IN ALASKA:SUMMARY OF EVENTS AND RESPONSE OF THE ALASKA VOLCANO OBSERVATORY 1994
}
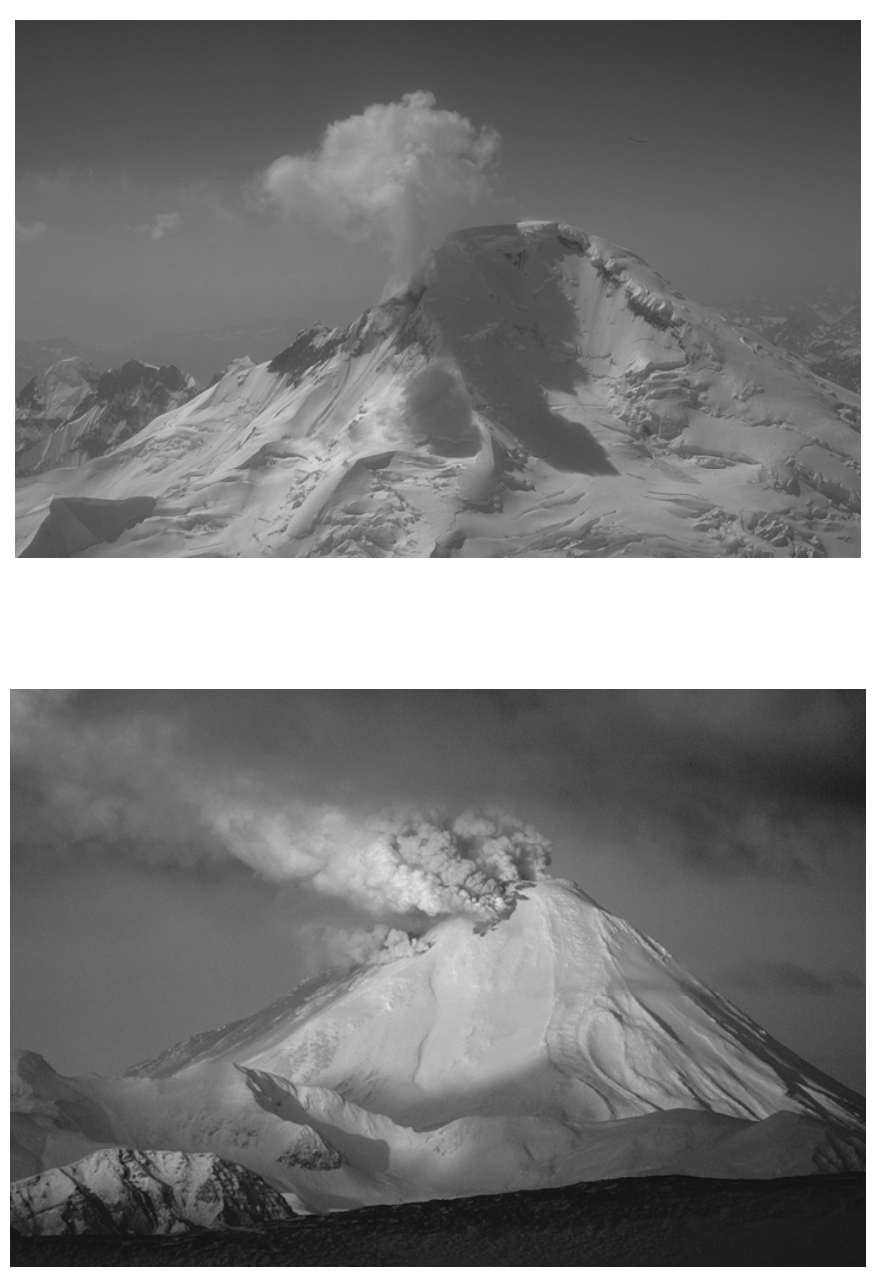

U.S. GEOLOGICAL SURVEY OPEN-FILE REPORT 95-271

By

Christina A. Neal, Michael P. Doukas, and Robert G. McGimsey 


\title{
U.S. DEPARTMENT OF THE INTERIOR
}

U.S. GEOLOGICAL SURVEY

\section{VOLCANIC ACTIVITY IN ALASKA: SUMMARY OF EVENTS AND RESPONSE OF THE ALASKA VOLCANO OBSERVATORY}

\author{
By \\ Christina A. Neal, Michael P. Doukas, and Robert G. McGimsey
}

Open-File Report 95-271

This report is preliminary and has not been reviewed for conformity with U.S. Geological Survey editorial standards or with the North American Stratigraphic Code. Any use of trade, product, or firm names is for descriptive purposes only and does not imply endorsement by the U.S. Government.1995 


\section{TABLE OF CONTENTS}

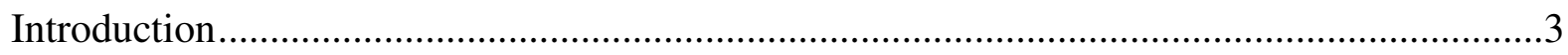

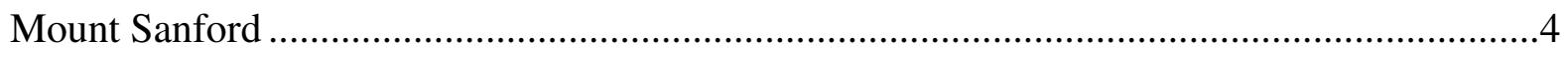

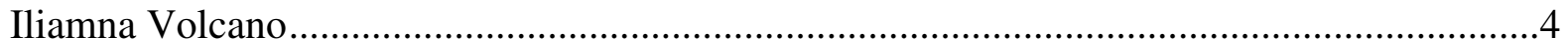

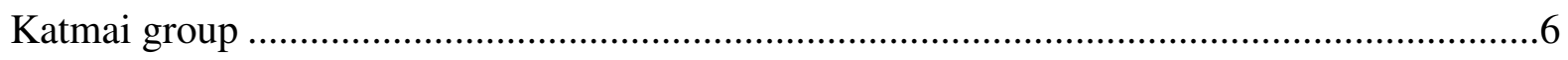

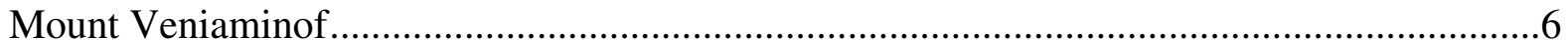

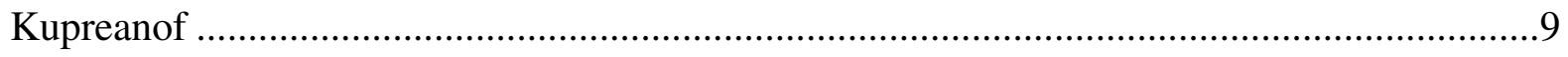

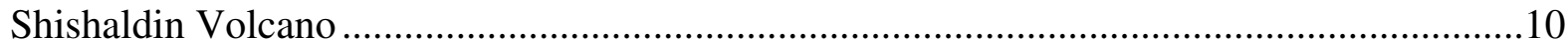

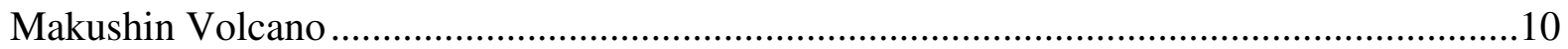

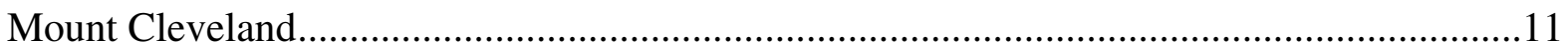

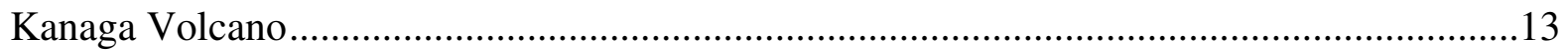

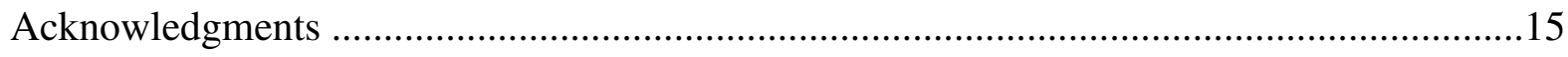

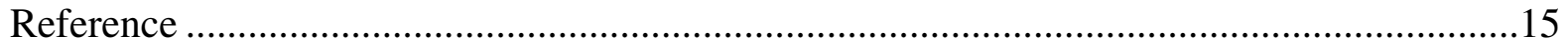

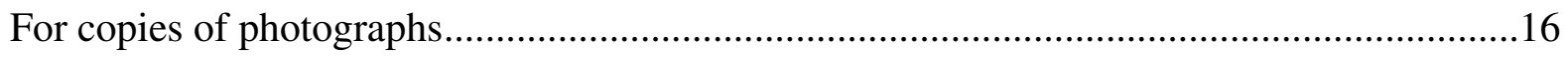

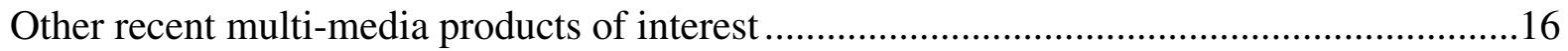

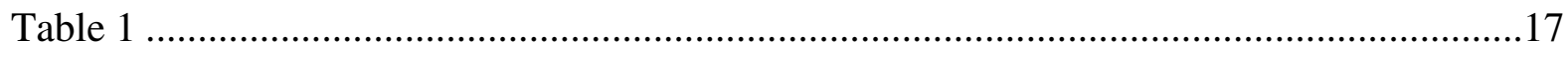

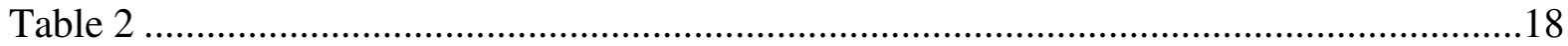




\section{INTRODUCTION}

During 1994, the Alaska Volcano Observatory (AVO) responded to eruptions, possible eruptions, or false alarms at nine volcanic centers--Mount Sanford, Iliamna, the Katmai group, Kupreanof, Mount Veniaminof, Shishaldin, Makushin, Mount Cleveland and Kanaga (table 1). Of these volcanoes, AVO has a real time, continuously recording seismic network only at Iliamna, which is located in the Cook Inlet area of south-central Alaska (fig. 1). AVO has dialup access to seismic data from a 5-station network in the general region of the Katmai group of volcanoes. The remaining unmonitored volcanoes are located in sparsely populated areas of the Wrangell Mountains, the Alaska Peninsula, and the Aleutian Islands (fig. 1). For these volcanoes, the AVO monitoring program relies chiefly on receipt of pilot reports, observations of local residents and analysis of satellite imagery.

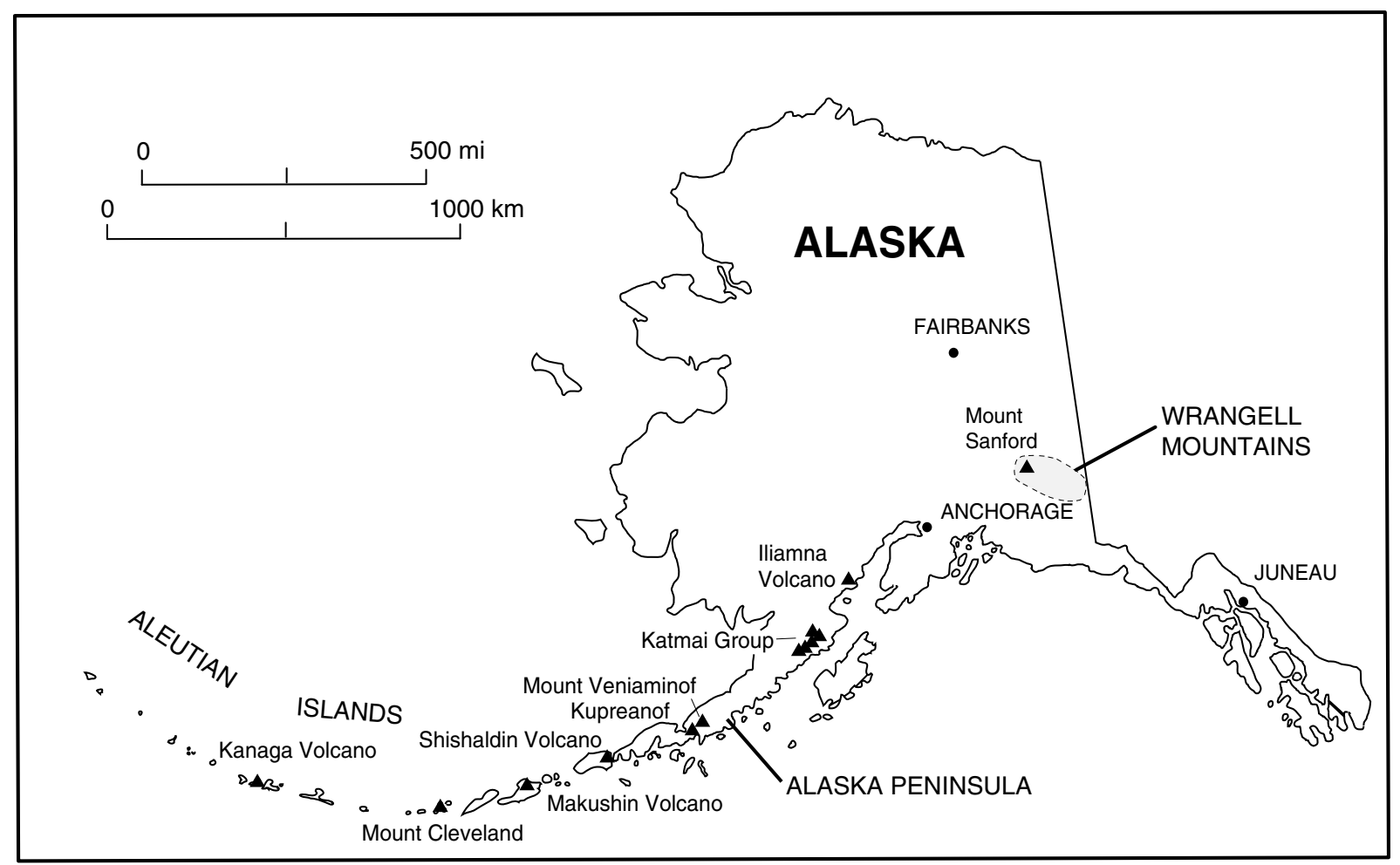

Figure 1. Locations of volcanoes (triangles) mentioned in this report.

This report presents a summary of volcanic activity in Alaska during 1994 and documents the AVO response. In this compilation, only those reports or inquiries which resulted in a "significant" investment of staff time and energy (here defined as an hour or more for reaction, tracking, and follow-up) are included. Typically, AVO receives many dozens of phone calls throughout the year reporting steaming, unusual cloud sightings, or eruption rumors. Most of these are dealt with very quickly and are not tabulated here as part of the 1994 response record.

Expanded descriptions of volcanic activity and the AVO response are presented in geographical order from northeast to southwest along the Aleutian volcanic arc. All elevations 
reported are above sea level (ASL) unless noted. A summary of volcanic activity is presented in Table 1. False alarms that required a significant response are summarized in Table 2.

MOUNT SANFORD
(FALSE ALARM)
Pilot report of steam plume from the volcano on 9/30/94; likely a result of avalanching of debris
off the steep south face.

Mount Sanford is a poorly-known, dissected shield volcano and the highest volcano in the Wrangell volcanic field. Its south face has a vertical relief of more than $2440 \mathrm{~m}$ (8000 ft; fig. 2). This precipitous wall is the source of nearly constant rock, snow, and ice-falls onto the Sanford Glacier. There is no record of historical eruptive activity at Mount Sanford; the youngest lavas are estimated to be 100,000 years old (Richter, 1991; Richter and others, 1995).

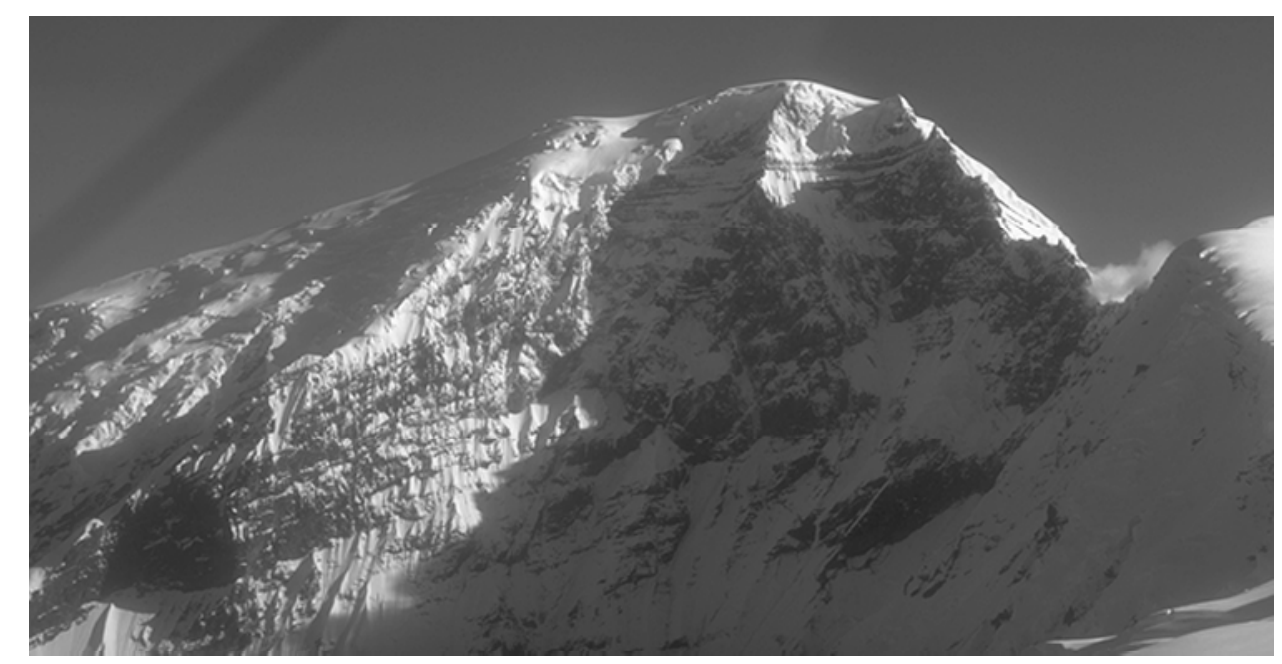

Figure 2. Precipitous south face of Mount Sanford in the Wrangell volcanic field. Photograph by anonymous, USGS, 1972.

On September 30, the National Weather Service (NWS) contacted AVO with a pilot report of a steam plume over Mount Sanford. AVO contacted the local flight service station in Gulkana and discussed the observation. Given the clear weather conditions at the time, the transience of the plume, and the history of large gravity slides at Mount Sanford, it was concluded that the observation was probably related to a large avalanche. No mention of this event was made in the AVO weekly update on volcanic activity in Alaska. 


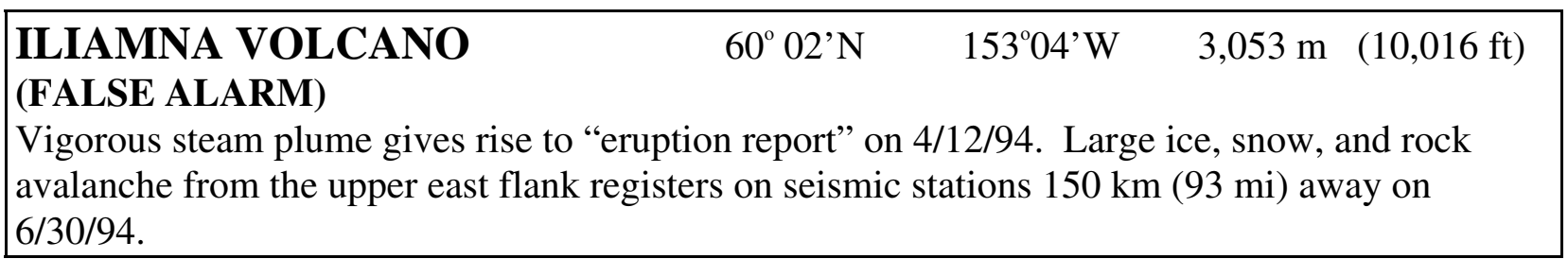

Iliamna Volcano is a glacier-carved volcanic peak located approximately $215 \mathrm{~km} \mathrm{(134}$ mi) southwest of Anchorage on the west side of lower Cook Inlet. Geologic studies of the volcano have thus far failed to find conclusive evidence of Holocene eruptive activity from Iliamna (Riehle, 1985). However, fumaroles located at about 2,740 $\mathrm{m}(8,990 \mathrm{ft})$ elevation on the eastern flank produce nearly constant plumes of condensate and minor amounts of sulfurous gases (fig. 3; Doukas, 1995). These plumes are quite vigorous and have resulted in numerous pilot reports of "eruptions" at Iliamna Volcano. AVO maintains four seismometers on Iliamna Volcano. A slow-scan television camera located on the Kenai Peninsula can be remotely aimed at the volcano to record real-time images.

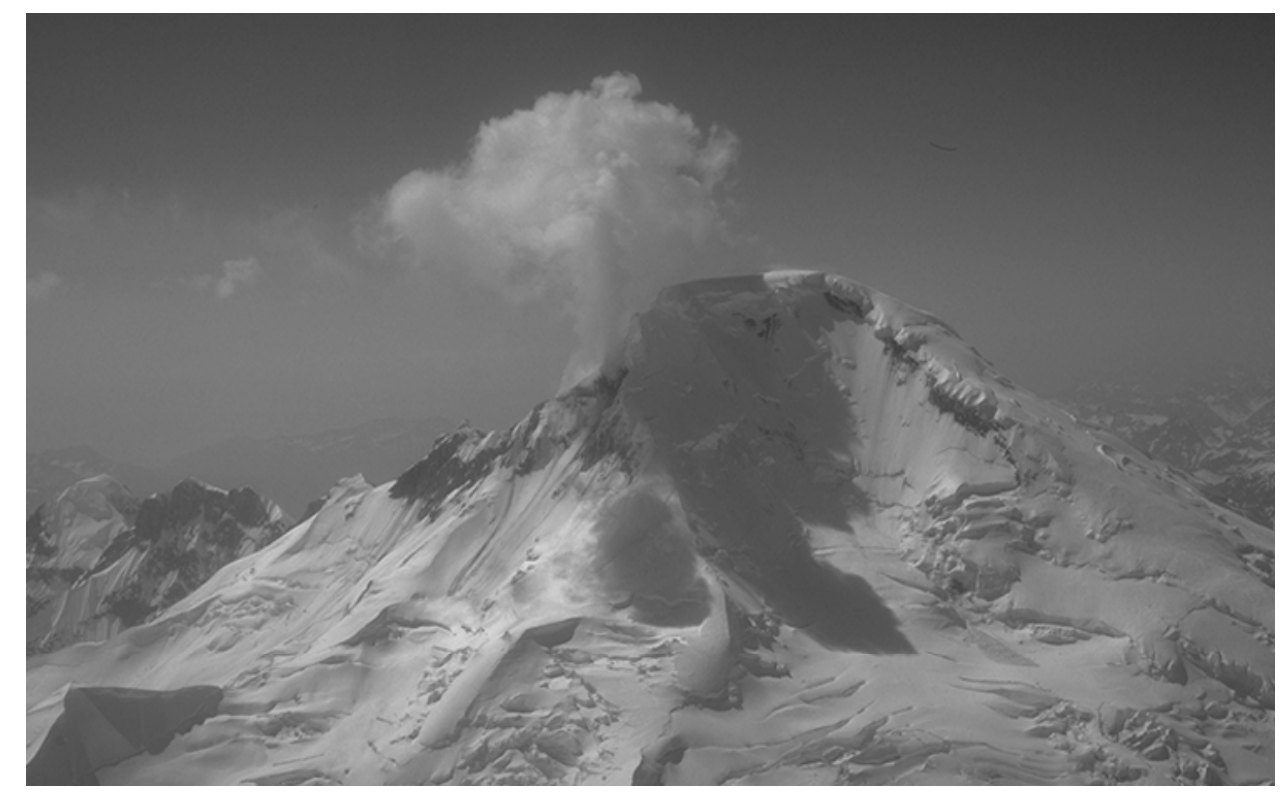

Figure 3. View of the glaciated north flank of Iliamna Volcano. A typical plume of steam and gas rises several hundred meters above the fumarole field. Photo by Robert McGimsey, USGS, $5 / 6 / 86$.

Pilot reports of an exceptionally large steam plume above Iliamna Volcano reached an AVO staff member at home on the night of April 12. The next day, at least one phone call from the local media indicated that word had spread about possible eruptive activity at Iliamna; AVO staff were able to examine seismic data and determine that the volcano was quiet. AVO also responded by including a comment in the weekly update about common sightings of benign (non-eruptive) steam plumes at Iliamna.

At 0939 Universal Time (UT) (1:39 am Alaska Daylight Time [ADT]) on June 30, a large avalanche from the upper east flanks of Iliamna Volcano produced a strong seismic signal as far away as station SLK at Skilak Lake on the Kenai Peninsula $150 \mathrm{~km}$ (93 mi) northeast of 
the volcano. Small shocks were recorded on Iliamna station INE (1585 m [5200 ft] on the northeast flank) as early as 0900 UT (1:00 am ADT); the main event at 0939 UT (1:39 am ADT) saturated the INE record for about 5 minutes. AVO staff examined the strong seismicity the next morning and quickly determined that it was not related to volcanic activity. This information was conveyed to Lake Clark National Park. AVO staff subsequently made observations on opportunistic fly-bys and spoke with pilots in the area.

The avalanche deposit was viewed and photographed on July 1 (fig. 4). The headwall is at about 2,200 $\mathrm{m}(7,220 \mathrm{ft})$ on the steep east face of the volcano and the avalanche itself extends 5-7 km (3-4.3 mi) to an elevation of approximately 525-600 m (1720-1970 ft).

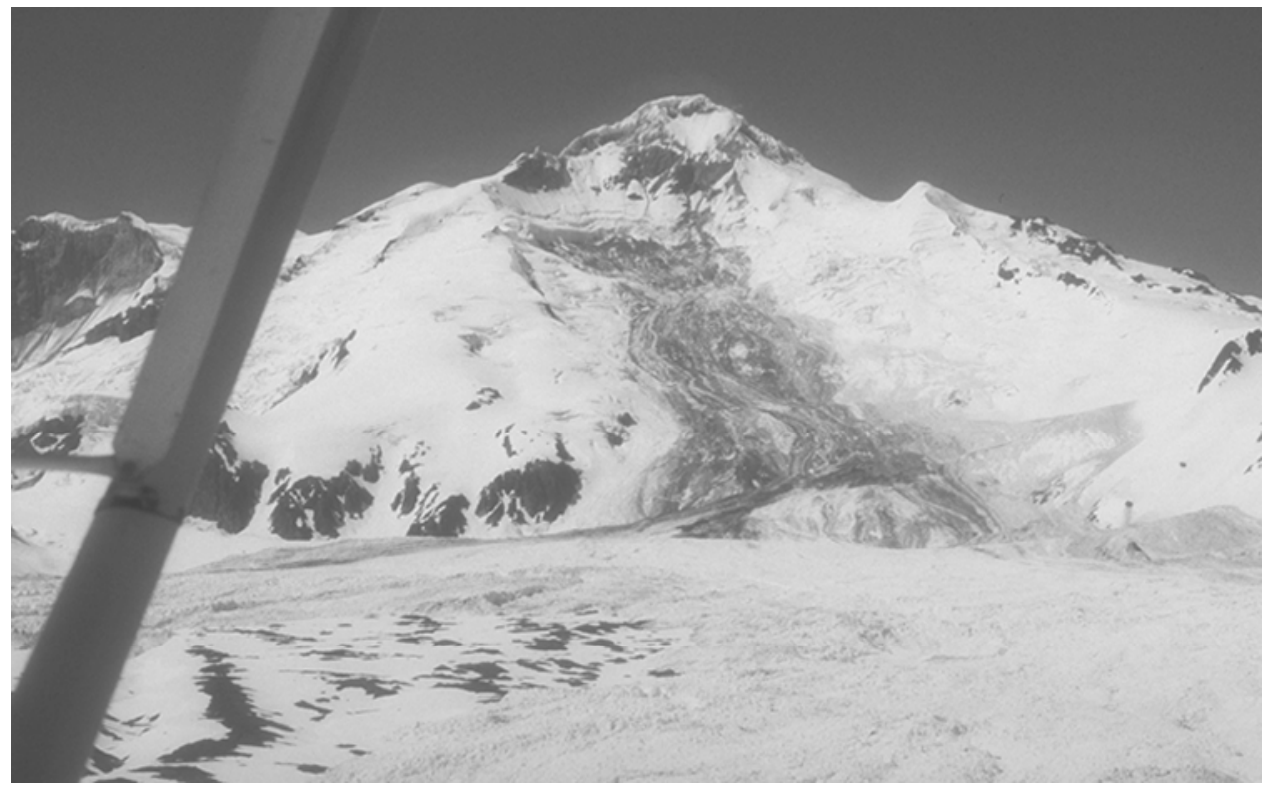

Figure 4. East flank of Iliamna Volcano. A mixed snow, rock, and ice avalanche deposit from the June 30, 1994 event is visible as the dark swath descending the east flank and turning to the left (south) out of the picture. Photography by National Park Service, 7/1/94.

$\begin{array}{llll}\text { KATMAI GROUP } & 58^{\circ} 16^{\prime} \mathrm{N} & 154^{\mathrm{o}} 59^{\prime} \mathrm{W} & 2047 \mathrm{~m}(6,716 \mathrm{ft}) \text { Katmai } \\ \text { (FALSE ALARM) } & 58^{\circ} 10^{\prime} \mathrm{N} & 155^{\circ} 21^{\prime} \mathrm{W} & 1860 \mathrm{~m}(6,102 \mathrm{ft}) \text { Martin }\end{array}$

Meteorological cloud on 12/5/94. [Note: For the purposes of this report, the Katmai group includes: Mount Katmai, Trident, Novarupta, Mount Mageik, Mount Martin (all contained within Katmai National Park and Preserve on the Alaska Peninsula.)]

The Weather Forecast unit at Elmendorf Air Force Base reported a plume-like cloud originating from the general region of the Katmai group and moving toward Kodiak Island on December 5. A satellite image indicated a possible hot spot at the source of the plume which appeared to be near the Mageik-Martin-Trident volcano cluster. AVO and NWS checks of concurrent satellite imagery showed nothing unusual and it was concluded that this was a meteorological phenomenon. A significant "false alarm" due to a similar meteorological cloud phenomenon at Mount Mageik in the Katmai group is described in McGimsey and others, 1995. 


\section{MOUNT VENIAMINOF $\quad 56^{\circ} 10^{\prime} \mathrm{N} \quad 159^{\circ} 23^{\prime} \mathrm{W} \quad 2,156 \mathrm{~m}(7,073 \mathrm{ft})$ active cone}

$2,507 \mathrm{~m}(8,225 \mathrm{ft})$ caldera rim

Intermittent strombolian eruptions produce steam and ash bursts typically $<1 \mathrm{~km}(3,280 \mathrm{ft})$ above volcano throughout the year. Lava flow issuing from the active cinder cone within icefilled summit caldera melts a pit $1 \mathrm{~km}(3,280 \mathrm{ft})$ across by May. Ash emission last observed in September. Occasional steam plume sightings over the volcano through year's end; hot spots in caldera detected by satellite intermittently into 1995 .

Mount Veniaminof is a composite stratocone located on the Alaska Peninsula about 800 $\mathrm{km}(500 \mathrm{mi})$ southwest of Anchorage. The volcano is truncated by an ice-filled summit caldera $8 \times 11 \mathrm{~km}(5 \times 7 \mathrm{mi})$ in diameter (fig. 5). Two cinder cones protrude through the ice-cap, one of which has been the locus of frequent historical eruptive activity at Mount Veniaminof. The current eruptive episode appears to be quite similar in style and magnitude to the 1983-84 eruption of Mount Veniaminof (Yount and others, 1985). The nearest settlements are Perryville, $34 \mathrm{~km} / 21 \mathrm{mi} \mathrm{SE}$, and Chignik Lake, Chignik Lagoon and Chignik, $40 \mathrm{~km} / 25 \mathrm{mi}, 55 \mathrm{~km} / 34 \mathrm{~km}$, and $60 \mathrm{~km} / 37 \mathrm{mi}$ ENE of the volcano, respectively (fig. 5). The village of Meshik/Port Heiden is on the Bering Sea coast $96 \mathrm{~km}(60 \mathrm{mi}) \mathrm{NE}$ of Mount Veniaminof.

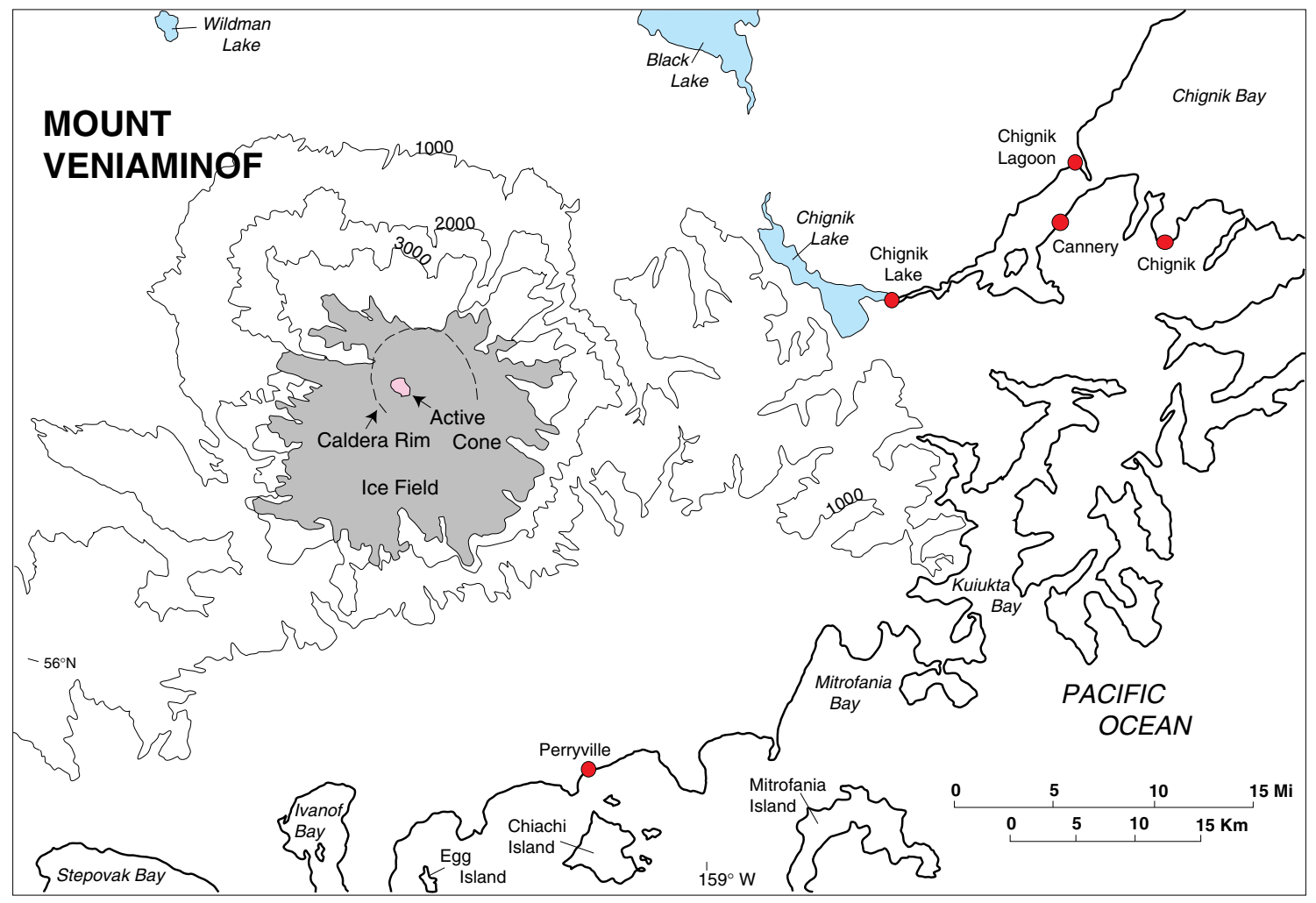

Figure 5. Map of Mount Veniaminof and surrounding area. For clarity, only selected contours $(C I=1000 \mathrm{ft})$ are shown.

The 1993-94 eruption began on July 30, 1993 (AVO phone logs, however, note a pilot report of steam emission from Mount Veniaminof on February 18, 1993). Over the next few months, pilots photographed minor ash and steam eruptions (fig. 6) and Perryville residents reported incandescence and rumbling noises. Minor ash fall occurred in Port Heiden on August 
3-4, 1993. A lava flow erupting from the intracaldera cinder cone was first observed and captured on video tape by the crew of a U.S. Coast Guard (USCG) flight in early November, 1993. Reports of eruptive activity diminished in frequency with the onset of bad winter weather; however, reports of renewed, intermittent strombolian activity reached AVO in March 1994. On May 9, 1994, during the first AVO overflight, eruptive activity consisted of quiet lava effusion from the vicinity of the intracaldera cinder cone (fig. 7). This lava flow had melted an oval-

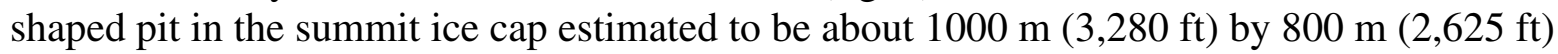
across and 30-50 m (100-160 ft) deep. Fractures in the ice surrounding the pit suggested subglacial melting. Unlike the 1983-84 eruption, no standing water was visible in the pit.

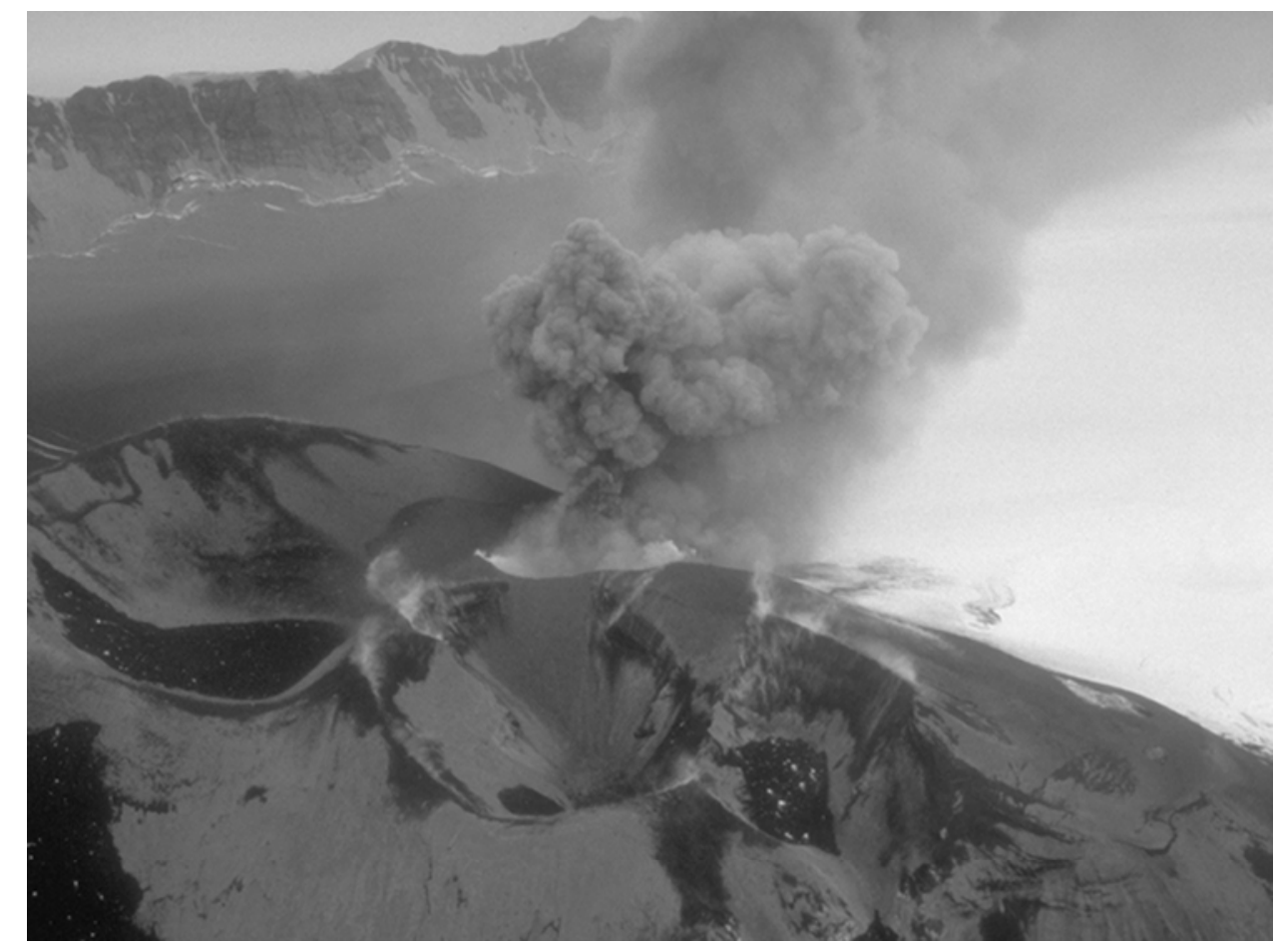

Figure 6. Ash eruption from the intracaldera cinder cone at Mount Veniaminof volcano. The craters at the top of the cone are approximately $100-200 \mathrm{~m}$ (328 - 656 ft) across. The caldera wall is visible at top, left. Photography by D. Sellers, Alaska Department of Fish and Game, $8 / 3 / 93$. 


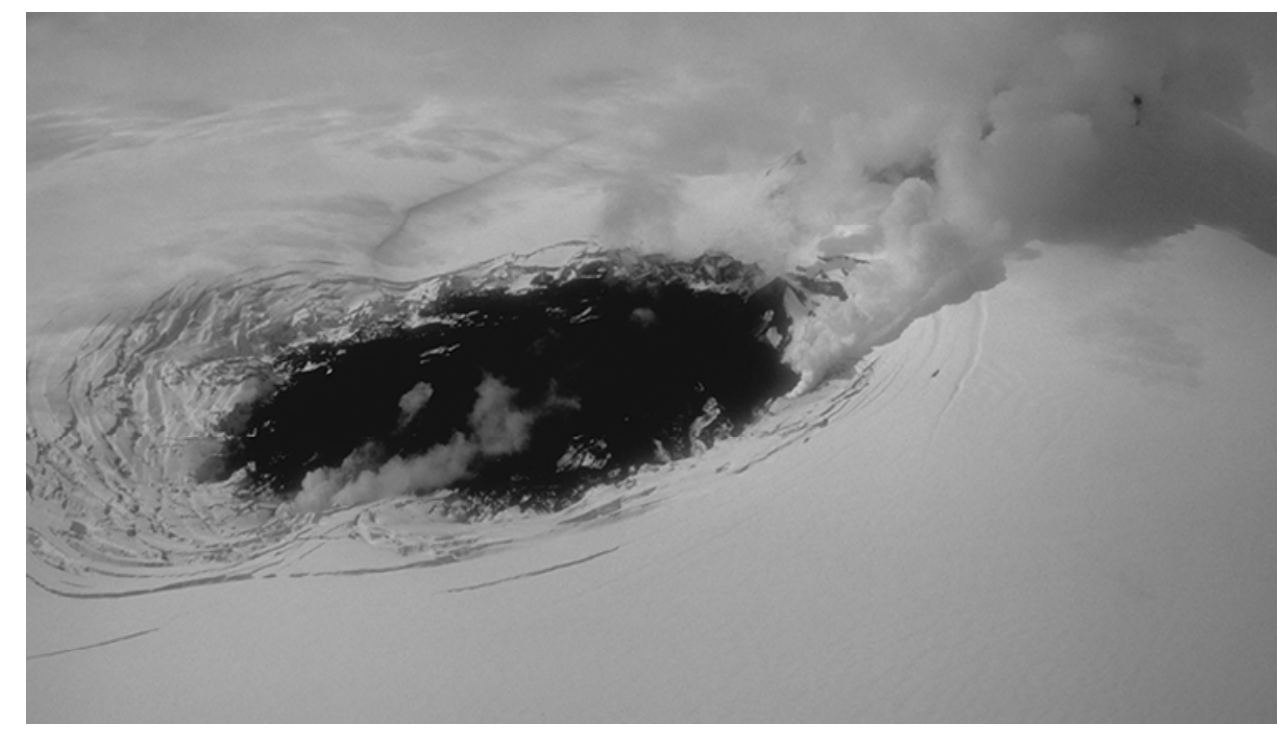

Figure 7. Lava flow accumulating at the base of the active intracaldera cinder cone (obscured by steam at upper right) at Mount Veniaminof volcano. Lava flow is melting a pit in the ice, approximately $1000 \times 800 \mathrm{~m}$ (3280 x $2625 \mathrm{ft})$ across. Photography by C. Nye, Alaska Division of Geological and Geophysical Surveys, 5/9/94.

On June 29, an especially vigorous eruption sent an ash cloud to a reported 4.8-5.5 km $(16,000-18,000 \mathrm{ft}$ ) and the NWS issued a SIGMET (notice of SIGnificant METeorological events.) Additional reports of low ash bursts over the volcano or incandescent strombolian activity viewed at night were received through mid-August. Steam plumes, at times rising several hundred meters, were reported over the volcano until late September. Due to the remote nature of this volcano, the paucity of observations, and the frequently poor weather, we are uncertain of the history of declining eruptive activity in late 1994. However, on Advanced Very High Resolution Radiometer (AVHRR) satellite images unobscured by heavy cloud cover, thermal anomalies were detected in the area of the active intracaldera cinder cone of Mount Veniaminof into early 1995.

The AVO response to this eruption at Mount Veniaminof in 1994 consisted of frequent (weekly or more often) communication with local residents, pilots, the USCG, and U.S. Fish and Wildlife Service (USFWS) personnel from the Alaska Peninsula National Wildlife Refuge to track progress of the eruption. A special information release was issued on June 29 and Mount Veniaminof activity was mentioned in AVO weekly updates until November 25, 1994 when it appeared the eruption had waned significantly or ceased altogether. As part of the routine response effort, AVO staff in Fairbanks conducted weekly evaluations of enhanced AVHRR images of the Mount Veniaminof area as weather conditions allowed throughout 1994 and into 1995.

\section{KUPREANOF \\ $56^{\circ} 0^{\prime} \mathrm{N}$ \\ $159^{\circ} 48^{\prime} \mathrm{W}$ \\ $1,890 \mathrm{~m}(6,201 \mathrm{ft})$}

Pilot report of unusually vigorous steam plume from the volcano on 7/22/94.

Kupreanof is a deeply eroded stratovolcano with no known historical eruptions. Holocene debris avalanche deposits have been recognized, however, and there is a vigorous fumarolic area marked by sulfur deposits at an elevation of 1,524 m (5,000 ft; fig. 8). Steaming 
from Kupreanof has been noted in the literature as "eruption reports" in the past (Smithsonian Institution, 1987). The nearest settlements are Perryville (45 km/28 mi ESE) and Port Moller $(48 \mathrm{~km} / 30 \mathrm{mi} \mathrm{W})$.

On July 22, a pilot reported a steam plume over Kupreanof reaching an altitude of 2,440 $\mathrm{m}(8,000 \mathrm{ft}$.) Although steaming from Kupreanof has been noted for at least the last 50 years, the robustness of the plume was considered unusual by this veteran pilot. No SIGMETS were issued by NWS, however, as no ash was detected. AVO took no further action.

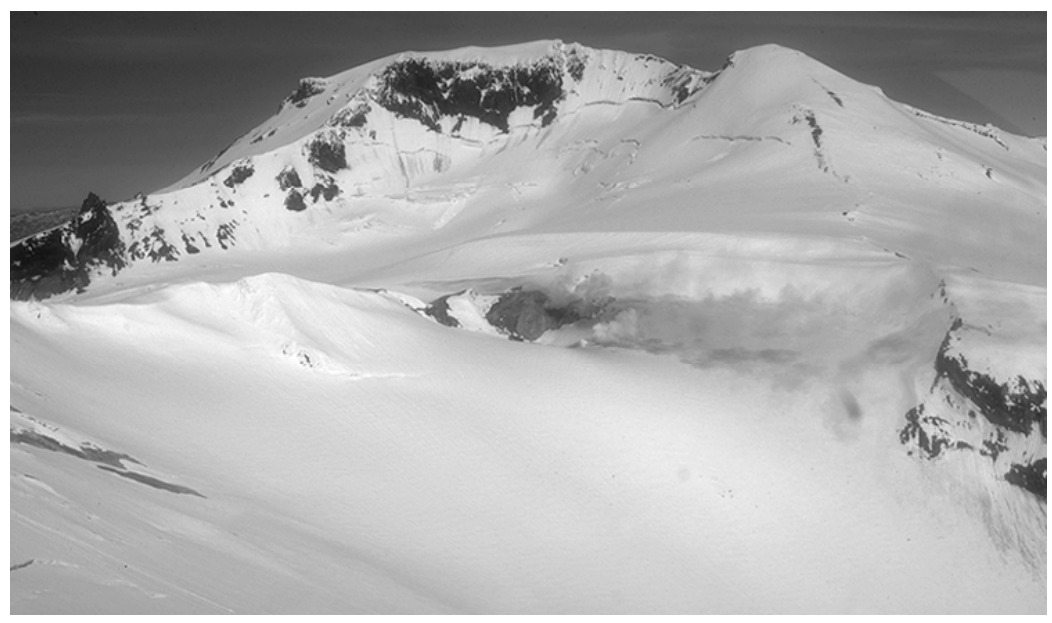

Figure 8. Summit area of Kupreanof volcano; active fumarolic area in center of photograph. Photograph by Thomas P. Miller, USGS, 1973.

\section{SHISHALDIN VOLCANO \\ $54^{\circ} 45^{\prime} \mathrm{N}$ \\ $163^{\circ} 58^{\prime} \mathrm{W}$ \\ $2,857 \mathrm{~m} \quad(9,373 \mathrm{ft})$}

Satellite image shows plume-like cloud on 5/23/94; subsequently confirmed to be meteorological. Possible ash eruption on 10/4/94; pilot report of steam plume $3 \mathrm{~km}(9,840 \mathrm{ft})$ above the volcano with minor amounts of ash.

Shishaldin Volcano, located about 1,100 km (680 mi) southwest of Anchorage on Unimak Island, is a spectacular symmetric stratocone (fig. 9) and is the highest peak in the Aleutian Islands. Shishaldin is one of the most active volcanoes in the Aleutian arc with at least 27 eruptions since 1775 (Alaska Volcano Observatory, unpublished data). Strombolian eruptions and ash and steam emissions characterize most of the documented eruptive activity at Shishaldin Volcano. Fumarolic activity within a summit crater produces a condensate plume that can be quite vigorous and results in numerous false eruption reports. 


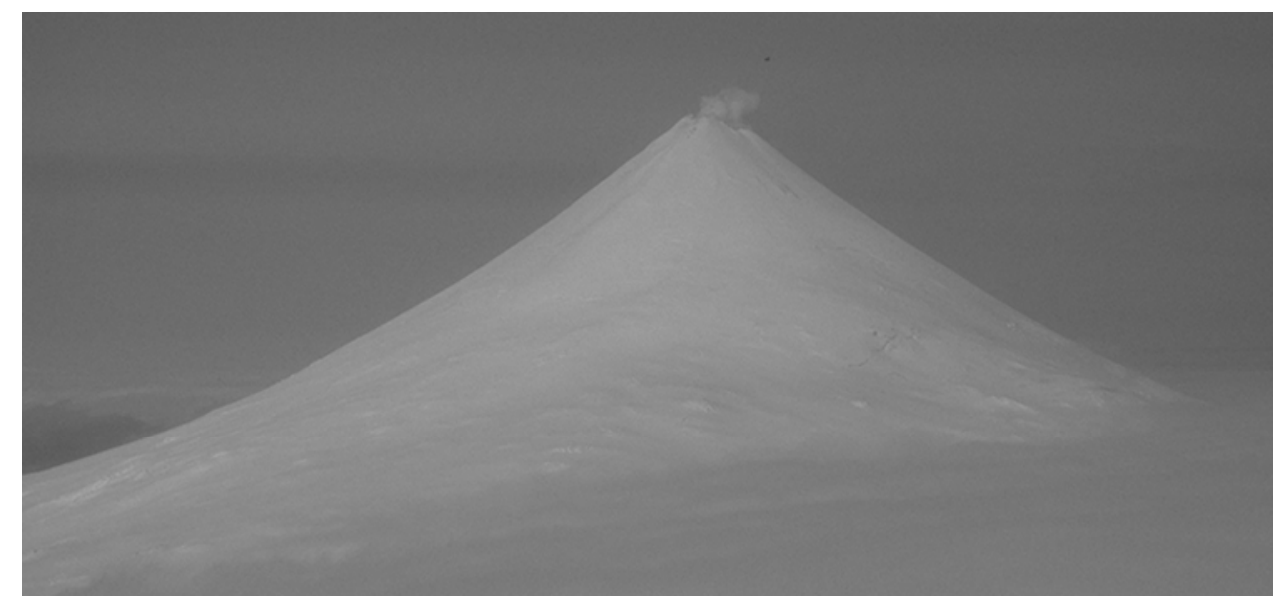

Figure 9. Symmetric Shishaldin Volcano rising 2,857 m (9373 ft) above sea level. Fumarolic activity within the summit crater produces a nearly continuous plume of steam. Photograph by C. Nye, Alaska Division of Geological and Geophysical Surveys, 5/9/94.

A plume-like image was recognized on an AVHRR satellite image prompting NWS to issue a SIGMET on the night of May 23, 1994. There were no pilot confirmations of any eruption and it is likely that this feature was a meteorologically enhanced fumarolic cloud.

AVO provided NWS with background information on fumarolic and eruptive activity at Shishaldin Volcano, fielded calls from an international air carrier about the alert and particle trajectory models released by the National Oceanic and Atmospheric Administration (NOAA).

\section{MAKUSHIN VOLCANO \\ $53^{\circ} 53^{\prime} \mathrm{N}$ \\ $166^{\circ} 56^{\prime} \mathrm{W}$ \\ $2,036 \mathrm{~m} \quad(6,680 \mathrm{ft})$}

Pilot report of possible steam and ash eruption on 1/19/94. Plume sighted 1,000 m (3,280 ft) above the summit.

Makushin is a broad, truncated stratovolcano located on Unalaska Island about 1,310 km (815 mi) southwest of Anchorage. A breached summit caldera contains a small cinder cone, eroded remnants of other cones, and several vigorous fumaroles (fig. 10). Other than minor phreatic emission, there is no record of historical eruptions at Makushin. The community of Unalaska and port of Dutch Harbor, important centers of population, commerce, and transportation in the eastern Aleutians, are located $25 \mathrm{~km}$ (16 mi) east of the volcano. 


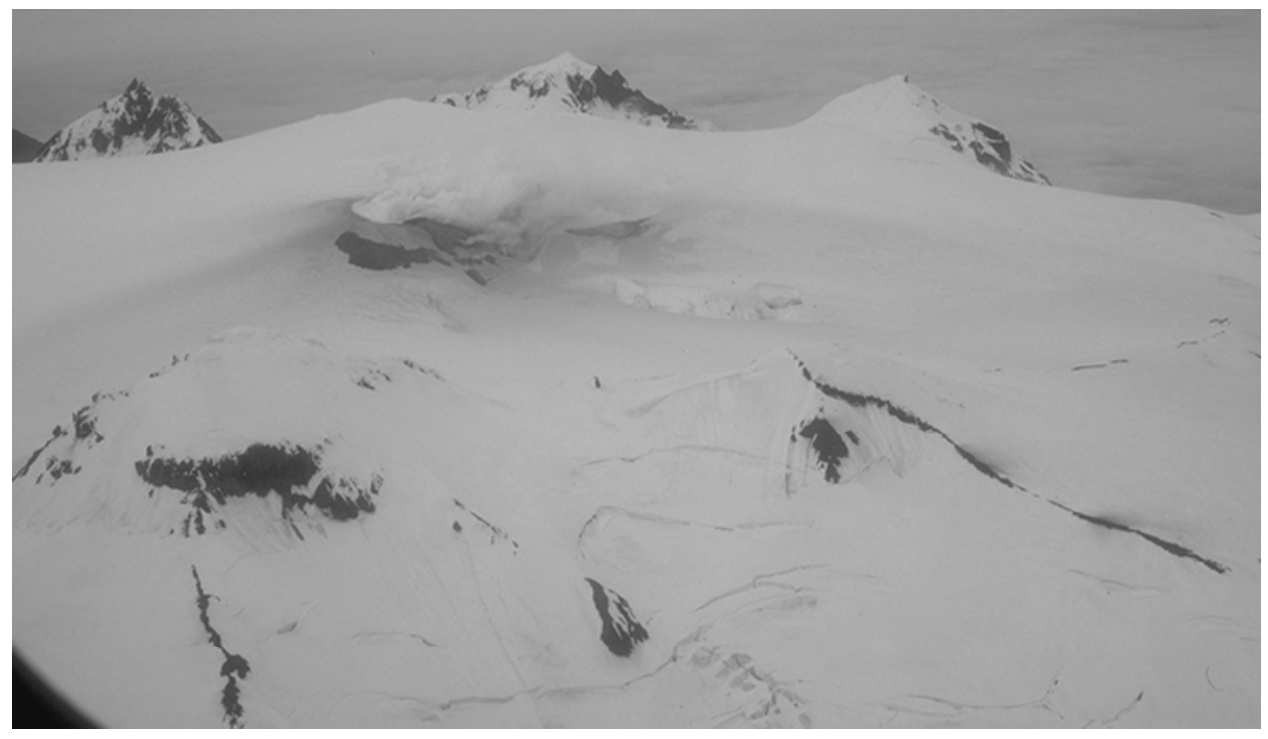

Figure 10. Aerial view of the summit area of Makushin Volcano. Steaming phreatic crater and snow darkened by ash visible in upper left center. Photograph by C. Nye, Alaska Division of Geological and Geophysical Surveys, 8/82.

On January 19, AVO received a pilot report of two distinct steam plumes, possibly containing ash, rising about $1,000 \mathrm{~m}(3,280 \mathrm{ft})$ above the summit of Makushin Volcano. AVO received at least one phone call from a major air carrier and one from the U.S. Air Force about the report. The NWS issued a SIGMET.

On January 21, an AVO staff member received a phone call from the Alaska Department of Emergency Services (DES) at 10:45 pm AST. The Chief of Police in Unalaska had contacted the DES to report a strong sulfur smell and unusual lightning. In addition to speaking to the Unalaska Chief of Police, AVO made phone contact with NWS watch officers to obtain satellite information and discussed possible scenarios with DES. It was concluded that the lightning was related to a strong frontal system and associated westerly winds. Additional reports of a robust steam plume were received on January 26.

AVO frequently receives reports of increased steaming at Makushin Volcano. Some observations suggest a small amount of ash is contained in these steam plumes; this is likely the result of vigorous fumarolic or minor phreatic activity.

\section{MOUNT CLEVELAND}

$52^{\circ} 49^{\prime} \mathrm{N}$

$169^{\circ} 57^{\prime} \mathrm{W}$

$1,730 \mathrm{~m}(5,676 \mathrm{ft})$

Unconfirmed pilot report of steam and possible ash emission on 4/29/94. Brief burst of ash to $\sim 10.7 \mathrm{~km}(35,000 \mathrm{ft})$ on 5/25/94, ash fall confined to the summit area and the north and east flanks of the volcano. Minor debris flows described on southwest flank. Satellite image shows possible (but unconfirmed) ash burst on 10/20/94.

Mount Cleveland is a symmetric stratocone which has been frequently active during the 20th century. The volcanic edifice forms the western half of Chuginadak Island (fig. 11) located about $40 \mathrm{~km}$ (25 mi) west of Umnak Island in the Central Aleutians about 1,525 km (950 mi) southwest of Anchorage. The most recent recorded eruption occurred in 1987 and, in addition to ash and steam emission, produced minor lava flows and a brief interval of lava fountaining from 
the summit crater (Smithsonian Institution, 1987). The nearest residents are in the village of Nikolski, about $50 \mathrm{~km}(37 \mathrm{mi})$ west of the volcano.

On April 29, pilots reported a robust steam plume, possibly containing ash, emanating from the volcano. Subsequent satellite image analysis did not confirm ash emission and, on May 10, AVO staff on an overflight of the eastern Aleutian arc saw no ash on the flanks of the partially cloud-shrouded volcano. On May 25, the NWS received two pilot reports of an ash cloud rising to an estimated 35,000 feet $(10.7 \mathrm{~km})$; several SIGMETS were issued. NWS and AVO analysis of enhanced AVHRR satellite imagery indicated one or possibly two small cloud patches drifting northeast from the volcano out over the Bering Sea. Based on pilot descriptions and analysis of the satellite image, the eruption was deemed a short-lived burst and not a sustained ash emission event. U.S. Fish and Wildlife (USFWS) personnel aboard the R/V Tiglax observed fresh ash on the north and east flank of the volcano and evidence of small debris flows on the southwest flank. AVO staff identified a possible ash plume from Mount Cleveland on VHRR imagery on October 20, however, no eruption was confirmed.

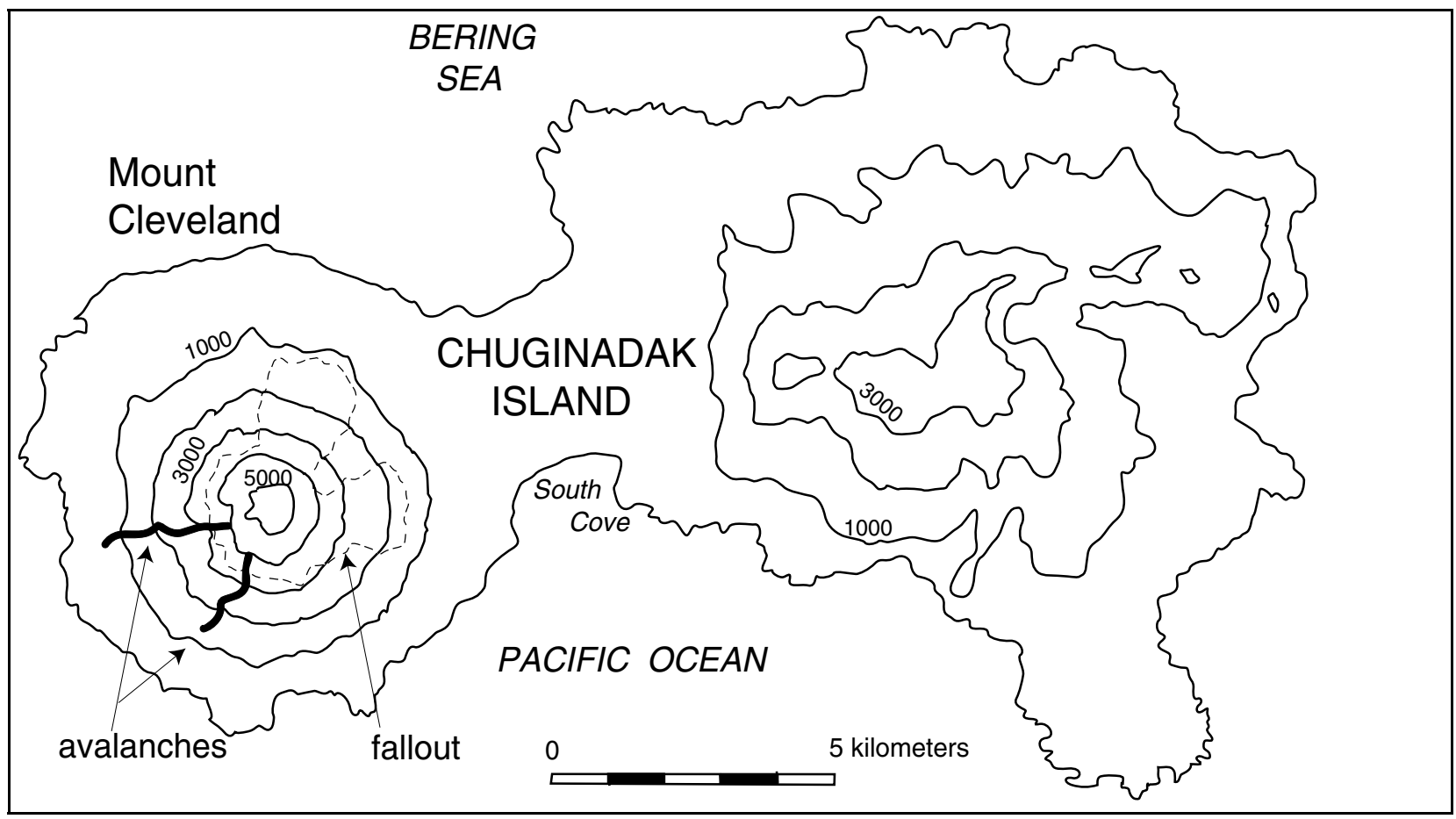

Figure 11. Sketch map of Chuginadak Island and Mount Cleveland volcano. Contour interval $1000 \mathrm{ft}$. Dashed line encloses area impacted by fallout from the 5/25/94 eruption based on observations of Jeff Williams, USFWS.

AVO issued no information release following either the April 29 pilot report or the October 20 satellite analysis because we could not confirm the presence of ash in the atmosphere. Following the May 25 event, however, based on the combination of pilot reports and satellite analysis, AVO released a statement of volcanic activity at Mount Cleveland. Several inquiries from air carriers were received throughout the night. Additional response efforts included analysis of satellite imagery, phone contacts with villagers in Nikolski, contact with the Aleutian marine radio operator to alert vessels, and compilation of pilot reports. 
KANAGA VOLCANO

$51^{\circ} 55^{\prime} \mathrm{N}$

$177^{\circ} 10^{\prime} \mathrm{W}$

$1,307 \mathrm{~m}(4,287 \mathrm{ft})$

Increase in steaming first recorded in April 1993. Intermittent ash and steam eruptions begin in January 1994, and continue possibly into October. Blocky lava flows fill summit crater and avalanche down northwest flank into the Bering Sea. Minor ash fall on the community of Adak, nearby fishing vessels, and brief interruption of air traffic in mid-August.

Kanaga Volcano is a symmetric stratocone located on the northern part of Kanaga Island in the western Aleutian Islands. Kanaga Volcano is $33 \mathrm{~km}(21 \mathrm{mi})$ west of the community of Adak (fig. 12). It has erupted numerous times since 1790. The last significant eruption was in 1906 when a series of lava flows moved down the northeast and southwest flanks. The community of Adak is largely military and the 1994 population was about two thousand at midsummer. [Note: with ongoing reductions in the U.S. Navy presence on Adak Island, this population figure is diminishing rapidly.]

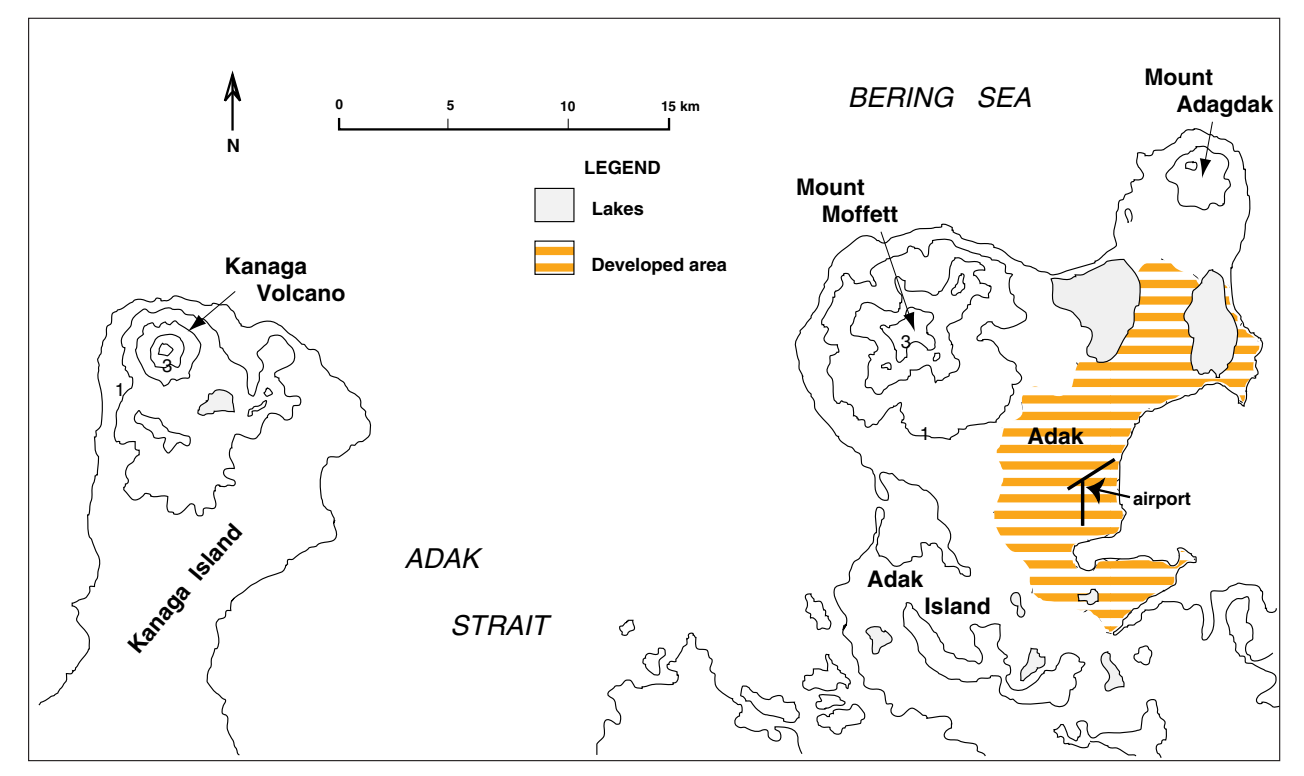

Figure 12. Sketch map of portions of Kanaga and Adak Islands. Contour interval $1000 \mathrm{ft}$. Approximate limits of the community of Adak taken from the 1957 edition of USGS topographic map Adak, Alaska (Alaska Topographic Series, scale 1:250,000).

Increased steaming from the summit crater and upper flank fumaroles was first reported to AVO on December 29, 1993. (However, AVO subsequently learned that pilots had noted increased steaming as early as April, 1993). Beginning in early January, 1994, minor ash plumes usually rising $<1 \mathrm{~km}(3,280 \mathrm{ft})$ over the summit were reported by pilots and residents of Adak. Photographs of Kanaga Volcano in late January confirmed that a linear vent system extended across the summit crater and part way down the east and west flanks. Ash and steam billowed 
from discrete segments of the vent and minor debris flow deposits, recognized as dark lobate tongues, extended from the trace of the fissure.

The eruption continued intermittently at a low level into October, 1994. Sightings of ash plumes were hampered by the frequent poor weather which plagues the Aleutian Islands. Most observed eruptive plumes were relatively dilute, rising to altitudes of $<3 \mathrm{~km}(9,840 \mathrm{ft})$ and dropping ash onto the flanks of the volcano. During other times, only white steam plumes were visible rising to altitudes of typically $<1500 \mathrm{~m}(4,920 \mathrm{ft})$ above the volcano's summit. At least two significant ash plumes were recorded over the course of this eruption: the first, to $\sim 7.5 \mathrm{~km}$ (24,600 ft) occurred on February 21 and the second on August 18, when an eruption cloud reached $\sim 4.5 \mathrm{~km}$ (14,760 ft; fig. 13). A light dusting of ash fell on the community of Adak on August 20. Air traffic was disrupted on August 22 due to continuing low-level activity and cloudy conditions which prevented visual approaches to the Adak air field.

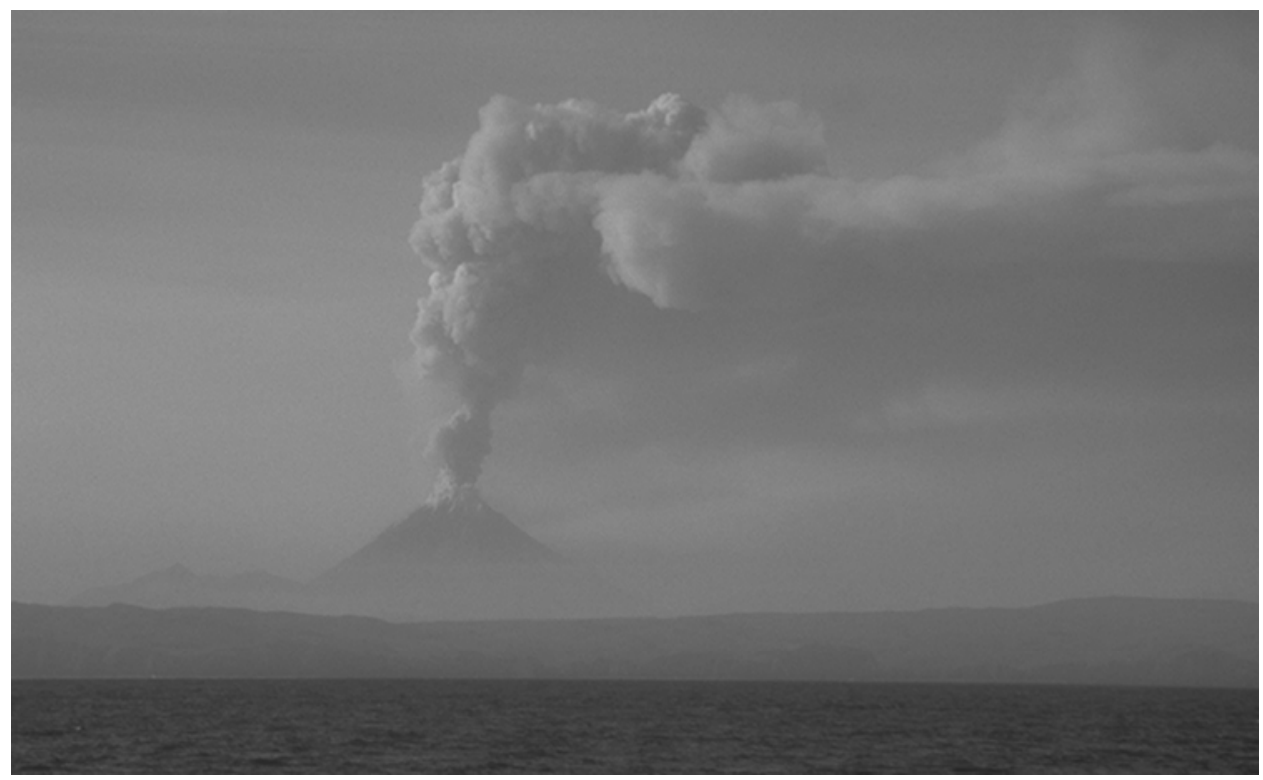

Figure 13. Kanaga Volcano in eruption as viewed from $42 \mathrm{~km}(26 \mathrm{mi})$ southeast of the volcano. Steam and ash plume rises approximately $3 \mathrm{~km}(9,840 \mathrm{ft})$ above the summit of the volcano and drifts to the east. Photography by J. Holm, 8/18/94. Used with permission.

Avalanching of incandescent fragmental debris down the north flank into the sea was first reported in April as "lava flows" by U.S. Navy pilots. On June 20 aboard the USFWS R/V Tiglax just offshore north of the island, Joe Meehan reported that at 1:45 a.m. local time, during a full moon, the crew observed two incandescent streams of fragmental material cascading down the northwest flank from an elevation of approximately $760 \mathrm{~m}(2490 \mathrm{ft})$ to near the shoreline. The upper flanks and summit of the volcano were obscured by clouds so the exact origin of the streams could not be determined. The crew could also not confirm whether debris had reached the ocean. By late July, however, USFWS personnel observed avalanches reaching the ocean and producing powerful littoral explosions. They noted that a new headland had been created.

Throughout 1994, Adak residents and pilots of aircraft approaching and departing Adak Island reported occasional sulfur smell under westerly wind conditions. AVHRR satellite imagery intermittently detected a hot spot near Kanaga Volcano summit through October 13.

AVO's response to this eruption, the most significant volcanic event in Alaska in 1994, included frequent contacts with USFWS and U.S. Navy personnel in Adak, consultation with 
NWS regarding interpretation of satellite imagery, acquisition of photographic and video documentation of activity, and successful solicitation of ash samples from Adak residents and marine vessel operators in the Aleutians. AVO staff participated in discussions about the possibility of deploying a portable radar unit from the Cascade Volcano Observatory, however difficult logistics and the low-level nature of eruption argued against the investment of time and money. AVO issued special information releases twice during the significant eruptions of midAugust and staff spoke directly with representatives of the two major air carriers servicing Adak. Kanaga Volcano was mentioned in weekly updates from January 14 to November 25, by which time it appeared from satellite and ground-based observations that the eruption had waned significantly or ceased altogether.

\section{ACKNOWLEDGMENTS}

Kathy Lemke provided invaluable graphics expertise to create the map figures in this report. Reviews by Doug Yager and Tari Mattox significantly improved the manuscript.

\section{REFERENCES}

Doukas, M.P., 1995, A compilation of sulfur dioxide and carbon dioxide emission-rate data from Cook Inlet volcanoes (Redoubt, Spurr, Iliamna, and Augustine), Alaska, during the period from 1990-1994: U.S. Geological Survey Open File Report 95-55, 15 p.

McGimsey, R.G., Neal, C.A., and Doukas, M.P., 1995, 1992 volcanic activity in Alaska: summary of events and response of the Alaska Volcano Observatory: U.S. Geological Survey Open File Report 95-83, 26 p.

Richter, D.A., 1991, Mount Sanford, in: Volcanoes of North America, C.A. Wood and Juergen Kienle, eds., Cambridge University Press, p. 87.

Richter, D.R., Rosenkrans, D.S., and Steigerwald, M.J., 1995, Guide to the volcanoes of the western Wrangell Mountains, Alaska: U.S. Geological Survey Bulletin 2072, 31 p.

Riehle, J.R., 1985, A reconnaissance of the major Holocene tephra deposits in the upper Cook Inlet region, Alaska: Journal of Volcanology and Geothermal Research, v. 26, p. 37-74.

Smithsonian Institution, 1987, Scientific Event Alert Network, v. 12, n.3, p. 10.

Smithsonian Institution, 1987, Scientific Event Alert Network, v. 12, n.6, p. 13.

Yount, M.E., Miller, T.P., Emanuel, R.P., and Wilson, F.H., 1985, Eruption in an ice-filled caldera, Mount Veniaminof, Alaska Peninsula, in Bartch-Winkler, Susan, and Reed, K.M., eds., The United States Geological Survey in Alaska, Accomplishments during 1983: U.S. Geological Survey Circular 945, p. 58-60.

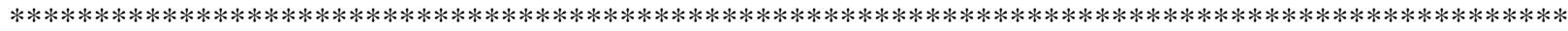
AVO is a cooperative program of the U.S. Geological Survey, University of Alaska Fairbanks Geophysical Institute, and the Alaska Division of Geological and Geophysical Surveys. AVO is funded by the U.S. Geological Survey Volcano Hazards and Geothermal Studies Program and the State of Alaska. 


\section{FOR COPIES OF PHOTOGRAPHS CONTAINED IN THIS REPORT:}

Duplicate 35-mm slides and prints of the images contained in this report (except the Kanaga photograph*) are available from:

The Photo Library

U.S. Geological Survey Photographic Library

MS 914 Box 25046 Federal Center

Denver, CO 80225-0046

303-236-1010

Digital versions (color and black and white) of images are available by contacting:

Christina Neal

U.S. Geological Survey

4200 University Drive

Anchorage, AK 99508

907-786-7456

tneal@tardaddy.wr.usgs.gov

(*The image of Kanaga in eruption is from the private collection of John Holm. He may be contacted at: 1414 NW 105th St. Seattle, WA 98177)

\section{OTHER RECENT MULTI-MEDIA PRODUCTS OF INTEREST:}

PHOTOGRAPHS OF THE 1992 ERUPTIONS OF CRATER PEAK, SPURR VOLCANO, ALASKA, USGS Open-file Report 93-707, 20 slides, 8 p. text and glossary, by Christina A. Neal, Robert G. McGimsey, Michael P. Doukas, and Inyo Ellerseick, 1993. 20-slide set illustrating aspects of the 1992 eruptions. Includes captions and glossary. Available from:

U.S. Geological Survey ESIC-Open-File Report Section

Box 25286, MS 517

Denver, CO 80225-0046

303-236-7476

VIDEO OF THE AUGUST 18,1992, ERUPTION OF CRATER PEAK VENT ON SPURR VOLCANO, ALASKA", by Robert G. McGimsey and Joseph M. Dorava, 1994, USGS Open-File Report 94-614. This 25minute, narrated video presents dramatic scenes of the second of three 1992 eruptions of Crater Peak, a satellite vent on Spurr volcano, Alaska. Favorable weather conditions permitted scientists from the Alaska Volcano Observatory to photograph the eruption from a fixed-wing aircraft flying as close as $2 \mathrm{~km}$ to the vent. The video includes closeup views of the roiling, 18-kilometer-high eruption column, shockwaves emanating from the column base, ash clouds from pyroclastic flows on the southeast flank, and ash fallout downwind.

10 YEARS OF VOLCANIC ACTIVITY IN ALASKA: 1983 TO 1992: A VIDEO", by Michael P. Doukas, Robert G. McGimsey, and Joseph M. Dorava, 1995, USGS Open-File Report 95-61. This 28-minute video presents eruption images from eight Alaskan volcanoes during the ten-year period: Veniaminof (1983-84), Augustine (1986), Redoubt (1989-90), Akutan (1991), Bogoslof (1992), Westdahl (1992), Spurr (1992), and Seguam (1992). Classic volcanic phenomena are documented, including meltwater lakes formed when lava flows advanced into an ice- filled caldera (Veniaminof), nighttime views of explosive strombolian activity (Veniaminof), pyroclastic flows descending steep flanks during plinian- and peleean- style eruptions (Augustine), hawaiian-style lava fountaining through glacial ice (Westdahl), island building in the Aleutians (Bogoslof), shock waves and close-up views of a roiling, sub-plinian eruption column rising more than 18 kilometers (Mount Spurr volcano-Crater Peak vent).

The videotapes are available from:

U.S. Geological Survey ESIC-Open-File Report Section

Box 25286, MS 517

Denver, CO 80225-0046

303-236-7476
AND KAKM Video ATTN: Penny Enders 3877 University Drive

Anchorage, AK 99508

Phone (907) 563-7070

US or Canada 1-800-684-3368

FAX (907) 273-9192

email71541.1216@compuserve.com 
Table 1. Summary of 1994 VOLCANIC ACTIVITY in Alaska (this includes actual eruptions, possible eruptions, and unusual increases in fumarolic activity). Location of volcanoes shown in figure 1.

\begin{tabular}{|c|c|c|}
\hline Volcano & Date of Activity & Type of Activity \\
\hline Kupreanof & 7/22/94 & pilot report of vigorous steam plume \\
\hline Mount Veniaminof & $\begin{array}{l}7 / 30 / 93^{a} \\
\text { to }^{\mathrm{b}}\end{array}$ & $\begin{array}{l}\text { strombolian eruption; intermittent steam and ash } \\
\text { bursts }<1 \mathrm{~km}(3,208 \mathrm{ft}) \text { over volcano throughout year; } \\
\text { lava flows issuing from the active cinder cone melt } \\
\text { pit in summit ice }\end{array}$ \\
\hline Shishaldin Volcano & $10 / 4 / 94$ & $\begin{array}{l}\text { possible eruption; pilot report of a steam to } 3 \mathrm{~km} \\
(9,840 \mathrm{ft}) \text { with minor amounts of ash }\end{array}$ \\
\hline \multirow[t]{2}{*}{ Makushin Volcano } & $1 / 19 / 94$ & $\begin{array}{l}\text { possible eruption; pilot report of steam and ash } \\
\text { plume } 1 \mathrm{~km}(3,208 \mathrm{ft}) \text { above summit }\end{array}$ \\
\hline & $1 / 26 / 94$ & pilot report of vigorous steam plume \\
\hline \multirow[t]{3}{*}{ Mount Cleveland } & $4 / 29 / 94$ & $\begin{array}{l}\text { possible eruption; pilot reports of robust steam } \\
\text { plume with possible ash }\end{array}$ \\
\hline & $5 / 25 / 94$ & $\begin{array}{l}\text { ash eruption; pilot report and satellite image of minor } \\
\text { ash cloud to } 11 \mathrm{~km}(36,080 \mathrm{ft}) \text {; ashfall confined to } \\
\text { north and east flank of the volcano; minor debris flows } \\
\text { on southwest flank }\end{array}$ \\
\hline & $10 / 20 / 94$ & $\begin{array}{l}\text { possible eruption; satellite detection of "hot } \\
\text { spot" at Mount Cleveland; no confirmation }\end{array}$ \\
\hline Kanaga Volcano & $\begin{array}{l}4 / 93^{\mathrm{c}} \\
\text { to } \\
10 / 13 / 94^{\mathrm{d}}\end{array}$ & $\begin{array}{l}\text { steam and ash plumes, usually }<1 \mathrm{~km}(3,208 \mathrm{ft}) \text { over } \\
\text { the summit intermittently throughout } 1994 \text {; avalanching } \\
\text { of hot debris from blocky lava flow down the } \\
\text { northwest flank into the sea; significant ash plumes } \\
\text { to } \sim 7.5 \mathrm{~km}(24,600 \mathrm{ft}) \text { altitude on } 2 / 21, \text { to } \sim 4.5 \mathrm{~km} \\
(14,760 \mathrm{ft}) \text { on } 8 / 18\end{array}$ \\
\hline
\end{tabular}

a earliest known eruptive activity recorded by AVO

b eruption possibly continues into 1995

c first sighting of increased steaming from Kanaga; AVO first received report 12/29/93

d last eruptive activity inferred from satellite imagery 
Table 2. Summary of FALSE ALARMS in 1994. A false alarm is defined as an eruption report or possible eruption report that is found to be normal fumarolic activity or weather-related or nonvolcanic phenomena. Location of volcanoes shown in figure 1.

\begin{tabular}{|c|c|c|}
\hline Volcano & Date of Activity & Type of Activity \\
\hline Mount Sanford & 9/30/94 & $\begin{array}{l}\text { false alarm; steam plume probably from snow/rock } \\
\text { avalanche reported by pilot }\end{array}$ \\
\hline Iliamna Volcano & $\begin{array}{l}4 / 12 / 94 \\
6 / 30 / 94\end{array}$ & $\begin{array}{l}\text { false alarm; pilot reports of anomalous steam plume } \\
\text { over Iliamna } \\
\text { false alarm; rock, snow, ice avalanche produces } \\
\text { strong seismicity }\end{array}$ \\
\hline Katmai Group & $12 / 5 / 94$ & false alarm; meteorological cloud \\
\hline Shishaldin Volcano & $5 / 23 / 94$ & false alarm; meteorological cloud \\
\hline Makushin Volcano & $1 / 21 / 94$ & false alarm; meteorological conditions \\
\hline
\end{tabular}

